\title{
Powerhouse of science? Prospects and pitfalls of place- based science and innovation policies in northern England
}

DOI:

10.1007/978-3-319-62560-7_5

\section{Document Version}

Accepted author manuscript

Link to publication record in Manchester Research Explorer

\section{Citation for published version (APA):}

Flanagan, K., \& Wilsdon, J. (2017). Powerhouse of science? Prospects and pitfalls of place-based science and innovation policies in northern England. In C. Berry, \& A. Giovanni (Eds.), Developing England's North: The Political Economy of the Northern Powerhouse (Building a Sustainable Recovery: SPERI Research and Policy Series). Palgrave Macmillan Ltd. https://doi.org/10.1007/978-3-319-62560-7_5

\section{Published in:}

Developing England's North

\section{Citing this paper}

Please note that where the full-text provided on Manchester Research Explorer is the Author Accepted Manuscript or Proof version this may differ from the final Published version. If citing, it is advised that you check and use the publisher's definitive version.

\section{General rights}

Copyright and moral rights for the publications made accessible in the Research Explorer are retained by the authors and/or other copyright owners and it is a condition of accessing publications that users recognise and abide by the legal requirements associated with these rights.

\section{Takedown policy}

If you believe that this document breaches copyright please refer to the University of Manchester's Takedown Procedures [http://man.ac.uk/04Y6Bo] or contact uml.scholarlycommunications@manchester.ac.uk providing relevant details, so we can investigate your claim.

\section{OPEN ACCESS}




\title{
Powerhouse of science? Prospects and pitfalls of place-based science and innovation policies in northern England
}

\author{
Kieron Flanagan ${ }^{1}$ and James Wilsdon ${ }^{2}$ \\ Published in Berry C and Giovanni A (eds) 2017 Developing England's North: The Northern \\ Powerhouse, Devolution and the Political Economy of Place. (Building a Sustainable Recovery: \\ SPERI Research and Policy Series. Palgrave). Reproduced courtesy of Palgrave Macmillan. \\ Available at: https://link.springer.com/book/10.1007/978-3-319-62560-7
}

'We've got an incredible opportunity to change the landscape of British science. I look at London and I see the largest research institute in Europe - the Crick Institute - being built. What's the Crick of the north going to be? Materials science? Nuclear technology? Something else? You tell me. Today I call on the northern universities to rise to the challenge, and come up with radical, transformative long term ideas for doing even more outstanding science in the north - and we will back you.' George Osborne, Chancellor of the Exchequer, 'We need a Northern Powerhouse', 23 June 2014 (Osborne, 2014)

Science and innovation are increasingly seen by the UK government as central to regional economic development policy, with a new emphasis on 'place' a prominent feature of related policy initiatives. Accordingly, science and innovation feature strongly in the discourse around the Northern Powerhouse. In this chapter, we unpick the rhetoric from the reality of science and innovation investment in the Northern Powerhouse. We ask whether policymakers will have the appetite to reverse the concentration of investment over recent decades in the London-Oxford-Cambridge 'Golden Triangle', and what decision makers in the North can do to harness science and innovation in support of wider development goals. And we look at the Northern Powerhouse science agenda through the prism of changing scholarly and policy thinking about the roles universities play as hubs for research and innovation, delivery agents for economic development and industrial strategy and as powerful actors in their local political economies.

From the launch of the Northern Powerhouse concept, science and innovation took centre stage. George Osborne's speech in June 2014, from which the quote above is taken, was delivered at the Museum of Science and Industry in Manchester, and peppered with

\footnotetext{
${ }^{1}$ Senior Lecturer in Science and Technology Policy, Manchester Institute of Innovation Research, Alliance Manchester Business School, University of Manchester (kieron.flanagan@manchester.ac.uk)

2 Professor of Research Policy and Director of Impact and Engagement, Faculty of Social Sciences, University of Sheffield (j.wilsdon@sheffield.ac.uk)
} 
references to technologies, old and new. Osborne drew attention to the techno-industrial heritage surrounding him, and went on to identify science and universities as one of four ingredients of his vision for the North's renaissance - alongside transport; creativity and culture; and the devolution of power.

After a decade in which 'impact' has risen in prominence to join 'excellence' as an explicit objective of UK science and innovation policy, 'place' now looks set to do the same (Greenhalgh et al., 2016; HMT/BIS, 2014). This shift was signaled in the December 2014 HM Treasury/BIS Our plan for growth strategy, developed by Greg Clark MP - in his then combined role as minister for universities, cities and science - and Sir Mark Walport, as Government Chief Scientific Adviser.

Money began to follow: most visibly through a $£ 235$ million commitment to the Manchesterbased Royce Institute for Advanced Materials Research and Innovation, the largest capital investment in science in the north of England in a generation. This was followed by a series of regional science and innovation audits, and further targeted investments.

The resignation of David Cameron as prime minister - and the departure of George Osborne has raised uncertainties about the level of continued government enthusiasm for the Northern Powerhouse. But the inclusion in the November 2016 autumn budget statement of a new $£ 2$ billion Industrial Strategy Challenges Fund suggests that place-based research and innovation policy is here to stay under May (Wilsdon, Flanagan \& Westlake, 2016).

The purposes to which the new fund will be directed forms part of the government's January 2017 consultation on its industrial strategy. But the aspiration to support local and regional economic development, alongside research excellence and priority technologies, is clear. As the consultation notes:

At present 46 per cent of Research Council and Higher Education Funding Council for England (HEFCE) funding is spent in Oxford, Cambridge and London...We could create new funding streams to support world-class clusters of research and innovation in all parts of the UK....In this way we will use some of the additional R\&D funding to help boost growth across the economy, as well as growing it overall. (HM Government, 2017) 
At the time of writing, Greg Clark is back at the helm as secretary of state in a renamed Department for Business, Energy and Industrial Strategy (BEIS). Sir Mark Walport has recently been announced as the inaugural chief executive of the new $£ 6$ billion per annum mega-funding agency UK Research and Innovation. And the release of a new Northern Powerhouse strategy, with 'enterprise and innovation' as one of its five themes, suggests that this aspect of George Osborne’s legacy may outlast him (HM Treasury, 2016).

\section{The role of place in science and innovation policy}

\section{Placeless excellence}

To understand the evolution of thinking about the role of place in science and innovation policy, we need to go back several decades. Research and higher education have often played an important part in the narrative and branding of redevelopment plans in several cities examples include the partially realised Manchester Higher Education Precinct of the 1960s, or the current interest in Knowledge Quarters and Innovation Corridors in cities such as Liverpool, Manchester and Newcastle. But prior to the 2000s, neither cities nor regions were a visible focus of national science and innovation policy (Perry, 2008).

One might expect innovation policy to have been more spatially aware, but until recently that has not been the case. In formal terms, policies and funding for science, research and technological innovation have historically been blind to geography. The focus has instead been on allocating public investment to curiosity-driven and problem-oriented research alike on the basis of 'excellence'. This criterion has been enacted through the prospective peer review of project proposals by the research councils, and by the retrospective review of published outputs submitted by universities through the regular cycle of research assessment exercises. The resulting geographical concentration of funds has not historically been seen as a matter for public debate (although private grumbles have of course been expressed).

From the 1980s, the UK government gradually withdrew from direct support for "nearmarket" R\&D, for largely ideological reasons. Prime Minister Margaret Thatcher (with her own background in industrial research) believed strongly that it was important for the taxpayer to continue to support so-called "basic" research, but that it was the role of industry to fund "applied" R\&D. Technology policy seen as a subset of industrial policy largely gave way to sector- and place-blind innovation policy, focused on efforts to promote technology 
transfer and the commercialisation of research findings through the encouragement of academic-industry links and increased patenting, licensing and spin-off activity. This implicit view of universities as factories of potentially exploitable knowledge also reflected the belief - widely held by politicians, funders and university leaders - that research universities had played a decisive role in the development of innovation super-clusters in the United States, including Silicon Valley and Boston's Route 128 (Flanagan and Keenan, 1998; Nightingale and Coad, 2014; Uyarra, 2010).

The UK's asymmetric governance has meant that Scotland, Wales and Northern Ireland have had some leeway with regard to science and innovation funding. They were able to establish their own economic development agencies and, after 1992, gained higher education funding bodies. New Labour's devolution accelerated this trend, granting elected assemblies and governments to the devolved nations and introducing administrative regionalism to England.

From its inception, New Labour's regional policy in England ascribed a central role to universities in the delivery of policies for economic and social development (Charles and Benneworth, 2001; Lawton Smith, 2007; Warren et al., 2010). The English Regional Development Agencies (RDAs) became the main delivery vehicle for sub-national economic development policies, including responsibility for the regional development funding mechanisms of the European Union. Incentives and funding for knowledge transfer and commercialisation strengthened over the same period, and some RDAs began to promote collaboration and strategic partnerships between universities, businesses and other organisations, aligned to regional social and economic development goals (Kitagawa, 2004).

\section{From regions to city-regions}

The trajectory of this developing 'territorialisation' of English universities was deflected by two developments in the 2000s. First, a controversial ministerial decision in 2000 politicised the spatial distribution of science spending in an unprecedented way. Second, the city-region emerged as a competing focus of attention to the larger RDA regions, and became the major focus following the demise of the English RDAs in 2010.

The controversy related to the decision to build a new 'fourth generation' synchrotron source - an advanced radiation source for investigating the structure of biological and nonbiological samples - at Harwell in Oxfordshire, rather than replacing the existing national 
synchrotron facility at Daresbury in Cheshire (mid-way between Manchester and Liverpool), where the human and technical capability to design and run such a facility was located.

The anger of local and regional stakeholders at this announcement caught the government by surprise, and as Perry (2007) notes, galvanised a new awareness of the uneven pattern of science spending across England. The decision was not reversed, but ministers felt forced to offer a consolation prize, in the shape of a modest regional science and innovation fund, and the creation of a North West Science Council, to develop proposals for future science and innovation activities.

Following the North West's lead, and encouraged by the subsequent House of Lords report on "Science and the RDAs" (House of Lords S\&T Committee, 2003), the other English RDAs set up similar councils, and the Northern RDAs in particular became active investors in science and innovation activities. Perhaps because resources were limited, or perhaps because of a lack of imagination, much of this activity followed the familiar science park and commercialisation route that the UK had already trod for decades. Meanwhile the concentration of investment in the Golden Triangle continued through the 2000s.

At the same time the notion of the city-region as a relevant unit of analysis and action was increasingly coming to the fore. The 'knowledge economy' thinking of the time lent itself particularly well to the notion: see for example the influential 2006 Work Foundation report Ideopolis: Knowledge City-regions, and the influence at that time in the UK - as elsewhere of the work of urban theorists such as Richard Florida (Nathan, 2015).

This new focus on city-regions gave rise to the 'Science City' initiative (Perry, 2008; Wray and Charles, 2009). In 2005, six cities across England (Birmingham, Bristol, Manchester, Newcastle, Nottingham and York) were named 'Science Cities'. The intention was to emphasise the potential for science to contribute to local economic growth, but there were no resources attached to this appelation, and it was completely delinked from any other aspect of national research funding.

The incoming coalition government announced the abolition of the English RDAs in 2010 . Instead they promoted the formation of Local Enterprise Partnerships (LEPs), typically focused on smaller (often city-regional) geographies. Unlike the RDAs, with their large 
devolved budget and staff, LEPs were to be bottom-up, private-sector led partnerships, with no core resources, but an ability to bid for grants from modest central funds (Bentley and Pugalis, 2013). Whatever science and innovation policy capacity the RDAs had managed to build up was quickly dispersed.

Meanwhile, central government support for applied technologies and innovation, channelled since the late-2000s through the Technology Strategy Board (later renamed Innovate UK) was also coming under criticism, for being geographically skewed towards the south of England. The initial geography of the new network of 'Catapult Centres' (inspired by the application-oriented network of Fraunhofer Institutes in Germany) did little to dispel this perception.

In the intervening period, academic and policy thinking about the roles of university and research organisations in the knowledge economy had evolved beyond a simple view of universities as 'knowledge factories' or sources of entrepreneurial spin-off activity, towards more nuanced notions of universities as active engagers, brokers and intermediaries, able to connect different actors across local, national and global networks (Uyarra, 2010).

Local and regional policymakers and analysts increasingly saw universities as powerful 'anchor organizations', by virtue of their local rootedness (CLES, 2015; Ehlenz, 2015; Lowe and Feldman, 2008). For their part, universities were quick to play up to such expectations, particularly when they came hand-in-hand with public funds or political support - but were sometimes subject to local criticism for failing to live up to their promises (Flanagan, Uyarra and Kitigawa, forthcoming).

\section{Will the real Powerhouse of Science please stand up?}

Northern England is home to twenty-three universities, including eight self-professed 'research-intensives' and other more teaching-oriented institutions. The histories of these institutions are often closely entwined with the civic, industrial and commercial development of their cities (Centre for Cities, 2015). In 2007, the eight research-intensive universities (Durham, Lancaster, Leeds, Liverpool, Manchester, Newcastle, Sheffield and York) set up the N8 group, to promote strategic collaboration in research. 
While it is certainly the case that the N8 universities are globally competitive research institutions, the results of the 2014 Research Excellence Framework show how comprehensively they are outperformed by Golden Triangle institutions in terms of research scale and critical mass (Else, 2015). Largely as a result of successive RAE/REF block funding allocations, the share of research funding going to universities in London, Oxford and Cambridge is still increasing: from $42.8 \%$ of all government funding allocated in England in $1997-8$ to just over $46 \%$ by 2013-14 (BIS, 2015, Table 3, p9).

The main driver of this growing gap is the increased selectivity in quality-related (QR) funding allocations over time. Figure 1 below compares five years of research council allocations and the projected five year allocation of QR funding (based on REF results) to four 'Golden Triangle' institutions and the University of Manchester (as an example of a leading Northern research university).

Sociologist Robert Merton (1968) famously noted that a 'Matthew effect' operates in science, so that prestige attracts rewards, which further increase prestige, and so on. The selectivity in QR funding seems to be outpacing even the 'natural' Matthew effect that emerges from the decentralised process of peer review involved in the allocation of competitive research council grants. This is unsurprising, as increasing the concentration of university research funding has been an aim of national research assessment since it was first introduced in 1986 (Flanagan and Keenan, 1998).

$<$ Figure 1 insert here $>$

Golden Triangle institutions benefit both from a positive feedback between funding and reputation, and from a geographical agglomeration of research activity, which makes them magnets for the best and brightest from all over the world. In particular, London and Cambridge offer an intensity of opportunities across a single scientific labour market (now labeled the 'London-Stansted-Cambridge Corridor'), which cannot be matched by any city in the North.

The labour market effects of agglomeration are such that, for a potentially mobile upcoming scientist from Barcelona, Boston or Bangalore, it will appear a much smaller personal and professional risk to uproot her career and family to move to one of the best known and most 
productive clusters of scientific and technological activity in the world, than it would to move to an apparently peripheral Northern city with a single research-intensive university. This calculation may remain the same even when the scientist is fully aware that the quality of her colleagues and facilities will be broadly similar, and that the cost of living will be lower and quality of life higher in the North.

The accelerated Matthew effect driven by the selectivity of English QR funding and the labour market effects of agglomeration in the Golden Triangle are mutually reinforcing. The outcome is that the North's research universities must run harder and harder simply to limit the ground they are losing, as the Golden Triangle institutions continue to pull away from the pack. One-off initiatives, even on the scale of the Royce Institute (which remains the largest science investment to date under the Northern Powerhouse agenda) barely make a dent, let alone reverse such trends.

A further setback to Northern hopes of a science-driven industrial renaissance has been the decision of the Anglo-Swedish pharmaceutical company AstraZeneca to relocate its main UK R\&D facility from its historical base at Alderley Park, just south of Manchester, to a new combined global R\&D centre and HQ in Cambridge (Rankin, 2013).

Local leaders understandably tend to feel great pride and satisfaction in the achievements of 'their university'. However this thinking can lead to complacency with regard to the relative lack of critical mass in research. So the shock that the supposed 'critical mass' of biomedical research and advanced training in Manchester was not in fact sufficient to retain AstraZeneca has had a similar effect on city-regional actors in the North West to that of the decision a decade earlier to site the Diamond Light Source synchrotron at Harwell, rather than Daresbury.

Furthermore, the Royce Institute typifies the persistent challenges that the North faces with regard to science and innovation. Although presented publicly - and regarded in Whitehall as the collective response of the N8 universities to Osborne's June 2014 challenge, there have been complaints from other Northern universities that Manchester broke ranks with its fellow N8 institutions to promote the Royce proposal, and that the decision bypassed input from the Research Councils and normal processes of peer review (McLeish, 2015). This has dented the 
trust that has been built painstakingly over recent years, between institutions that have traditionally seen each other as direct competitors.

Another interesting contrast can be drawn with flagship science investments in London, such as the Sir Francis Crick Institute for biomedical research, which opened in 2016. Although the government's commitments to constructing and equipping the Royce and the Crick are in the same ballpark, the Crick's total capital budget, including contributions from charitable funders such as the Wellcome Trust and Cancer Research UK, is around $£ 700$ million, so three times larger (Callaway, 2015).

Furthermore, the Royce will have its main 'hub' in Manchester supplemented by northern 'spokes' at the Universities of Sheffield, Leeds and Liverpool, and additional Golden Triangle 'spokes' at Cambridge, Oxford and Imperial College. Perhaps because the latter aspect sits so uneasily with hits Northern Powerhouse rhetoric, George Osborne omitted to mention the Golden Triangle spokes in his initial announcement about the Royce to the House of Commons, in his 2014 autumn budget statement.

It is also worth noting that Crick Institute has no spokes at all, let alone in the North. Indeed, when Sir Paul Nurse, the Crick's director, was asked by the Financial Times how the new institute would play a 'national' role, he argued that only by being based in London could the Crick play an effective national role (Cookson, 2013). His clear implication was that to be located anywhere else would be to accept provincial status.

\section{Place-based policy redux}

So the picture remains mixed. However, as we shall show, there are signs that the government may be ready to rethink the effects of decades of intensifying concentration in research and innovation funding. We have already noted that the most striking feature of the Coalition's science and innovation strategy, published at the end of 2014 (HMT/BIS, 2014) was the emphasis it placed on the role of science and technology in 'place-making'. The subsequent 2015 budget (HMT, 2015) went further in identifying a role for science in regional economic development, and inviting "universities, cities, LEPs [local enterprise partnerships] and businesses to map strengths and identify potential areas of strategic focus for different regions" through a series of 'science and innovation audits'. 
The short-lived tenure of Sajid Javid as Secretary of State for Business, Innovation and Skills, following the 2015 election, seemed to herald a retreat from industrial strategy and a tentative interest in the connections between science, innovation and place. The prevailing rhetoric reverted to emphasis sector- and space-neutral innovation policy and an industrial 'approach', over proactive strategy (Rigby, 2015). Javid's most visible enthusiasm was for cost cutting, and he called in the consultancy firm McKinsey to develop a 'BIS 2020' plan to slash budgets, staff numbers and the number of BIS-funded public bodies (Wilsdon, 2015). This included the closure of the BIS office in Sheffield, its largest anywhere outside London, with a loss of 250 skilled civil service jobs - hardly a vote of confidence in the Northern Powerhouse (Perraudin, 2016).

But following the post-EU referendum changes at the top of government in summer 2016, which saw the return of Greg Clark as Secretary of State to the renamed BEIS (Department for Business, Energy and Industrial Strategy), the agenda that he set out in the Our plan for growth strategy has been dusted off. Place-based policymaking is once again in the ascendant.

One of the commitments in that 2014 strategy - for an initial series of regional 'science and innovation audits' - has now been delivered (BEIS, 2016), and a second wave is on the way. It remains to be seen how these audits will inform future science and innovation spending. The LEPs appear to have interpreted the task primarily as producing a brochure listing their science and innovation assets, rather than of conducting a detailed warts-and-all analysis of strengths, weaknesses and opportunities (McKenzie, 2016).

The audits come at the same time as a new wave of devolution deals for metro cities, raising the possibility that science and innovation may become an area of focus for emerging cityregional authorities. And the January 2017 industrial strategy Green Paper consultation (HM Government, 2017) seems open to the possibility of some tentative regionalisation of science and innovation spending in England.

However, the policy of geography-blind, excellence-based science policy and funding remains dominant. The imminent re-organisation of the UK Research Councils, Innovate UK and the research functions of HEFCE into a single, powerful body called UK Research and Innovation complicates the picture (BIS, 2016; Wilsdon, 2016), not least because ministers have had to make assurances about autonomy and excellence in order to smooth the passage 
of the enabling legislation (still under debate in the House of Lords, at the time of writing). Assuming all is well UKRI will formally come into existence on 1 April 2018. It will be led by the other architect of the 2014 Our plan for growth strategy - Sir Mark Walport - who will move from his current role as chief scientific adviser, to become UKRI's inaugural CEO (Flanagan, 2017).

QR funding will also fall under the new UKRI structure, and debates are now intensifying about the design of the next Research Excellence Framework (scheduled for 2021). Following a review by Lord Stern, a consultation is underway about reforms intended to reduce the burdens of the REF and minimise its unintended effects (HEFCE, 2016). But while the consultation raises lots of important issues around the design and operation of a national assessment exercise, it does not question the philosophy behind how the REF scores are used to drive increasing concentration of funding in London and the South East. So far, there has been surprisingly little public debate about the QR formula and whether selectivity may have gone too far.

How decision-making will operate across the new consolidated funding body is not yet clear. One of the strongest arguments that government has made in favour of UKRI's creation is that it will enable more strategic, system-wide analysis of the opportunities for closer alignment between research strengths and economic, industrial and social priorities - with the new industrial strategy one prominent strand of this (BIS, 2016; Kingman, 2016). At the same time, the notional arms-length relationship between ministers and the UKRI board and chief executive, means that some decisions (for example, over the QR formula), will be made a step further away from wider government policymaking on industrial strategy and spatial rebalancing.

Meanwhile, rumoured discord within the N8 group of research universities, the resistance of some local authorities to joining forces in combined authorities, and the continued tendency for some local leaders to be captured by the interests of 'their universities' all pose significant challenges to the development of a distinctive Northern agenda for science and innovation.

\section{Conclusion: taking back control?}

The centrality of science and innovation to the original vision of the Northern Powerhouse illustrates both Osborne's genuine enthusiasm, and a significant body of empirical evidence 
in support of the linkages between universities, research, innovation and regional economic growth. Science and innovation investment is rarely seen through a party-political lens: it is typically presented as a straightforward investment in the future. It also delivers newsworthy announcements and photo opportunities at a fraction of the cost of transforming local or regional transport infrastructure.

The emerging industrial strategy (and its linked $£ 2$ billion challenge fund), the creation of UKRI, and the active support of ministers like Greg Clark, suggests that place-based policies for science and innovation will continue to garner political attention and focus. Whether there will be any significant shift in investment patterns across England is harder to predict. The design of UKRI certainly gives Walport and his board the scope to make such changes, either through further large capital investments, or through tweaks to the QR formula in the next REF. At the same time, wider uncertainties in the research landscape - particularly linked to Brexit and a potential reduction in European sources of funding (which currently amount to around $£ 850 \mathrm{~m}$ of research grants to the UK each year, not to mention science and innovation projects supported with EU regional development funds) - may overwhelm modest moves towards a place-based rebalancing of investment. The additional investment promised through the Industrial Strategy Challenges Fund may end up simply plugging a hole created elsewhere in research budgets by a 'hard' Brexit.

In the North, greater critical mass is required for science and innovation to deliver substantial change. Worsening regional disparities in terms of science activity need to be addressed, and this cannot be done through one-off initiatives such as the Royce, however impressive these are on their own terms. Instead, serious reforms are required to the funding policies that underlie these disparities. This means actively reversing, or at the very least halting, the explicit drive for greater concentration of research funding that has characterized English research policy for decades. Will UKRI really have the appetite to take resources from the Golden Triangle, and give them to the North? As Dame Athene Donald wrote recently, "Squaring politics, geography and excellence, in a way that satisfies both politicians and the wider research community, will be no mean feat" (Donald, 2017).

Other crucial success factors for science and innovation are common to all elements of the Northern Powerhouse. Endlessly-discussed but slow-to-progress inter-Northern public transport improvements hold some potential to replicate the labour market effects generated 
by the Golden Triangle agglomeration of research activity, at least between some cities. At the same time, regional and local leaders in the North need to be more realistic about what investment in research can and cannot buy them. The persistent yet misguided belief that the growth of super-clusters like Silicon Valley and Route 128 is the direct result of the exploitation of research done in top universities has resulted in what we might call the 'closed system fallacy'. This suggests that, because scientific discovery A takes place in country/region/city/university A, then it follows that it should be commercialised in the same place.

But however strong Northern science is, there will always be far more scientific and technological R\&D going on elsewhere. Though scientific and technological knowledge is often 'sticky', it is produced in complex global collaborations, and flows rapidly from node to node. Proximity is important - but there are other kinds of proximity, in addition to spatial proximity. There is no reason to suppose that discovery, commercialisation and innovation should normally happen in the same place. Indeed the odds are against it.

What research strengths buy for any region is the capacity to understand, evaluate, absorb and use knowledge that has been developed elsewhere (Bhidé, 2010). But these strengths come with no guarantee of economic, industrial or commercial success: they are primarily an entry ticket into global science and technology networks.

The North needs to attract and retain more talented researchers from across the UK and beyond, Brexit notwithstanding. The lower cost of living is not going to be enough to counter the Golden Triangle effect - even as costs soar there. If the funding formula that drives the Golden Triangle effect is not loosened, then critical mass must be built in other ways. Improving transport links between Northern university cities could help, but political leaders must also avoid letting their understandable pride in the local research university lead to their capture by that institution.

Courageous leaders could, for instance, work to attract top foreign universities to open research and teaching facilities in their cities. Legitimate concerns have been raised about the changes being introduced through the current Higher Education \& Research Bill (Curry, 2016). But the government's interest in allowing 'new entrants' into English higher education need not start and stop at private, for-profit degree mills. This may be made more difficult by 
Brexit - but surely not impossible. EU universities, US universities and even Scottish universities might all be enticed to invest in research and teaching activities in the North with the right incentives. This could be one step towards building a genuine powerhouse of science in the North. 


\section{References}

BEIS, 2016, Science and Innovation Audits: Wave 1 Summary Reports. London: Department for Business, Energy and Industrial Strategy, November 2016

Bentley, G. and Pugalis, L. 2013, "New directions in economic development: Localist policy discourses and the Localism Act" Local Economy 28(3): 257-274.

Bhidé, A, 2010, The Venturesome Economy: How Innovation Sustains Prosperity in a More Connected World. New York: Princeton University Press.

BIS, 2015, Public Research and Innovation Expenditure: Geographic breakdown of public research and innovation expenditure. London: Department for Business, Innovation and Skills, June 2015.

BIS, 2016, Case for the creation of UK Research and Innovation. London: Department for Business, Innovation and Skills, June 2016.

BIS, 2015, Public Research and Innovation Expenditure: Geographic breakdown of public research and innovation expenditure, June 2015, Department for Business, Innovation and Skills.

Callaway, E., 2015, Sir Paul's Cathedral: Europe's Superlab. Nature Vol 552: 7557, pp 406408.

Centre for Cities, 2015, Northern Powerhouse factsheet: key figures on the city regions in the Northern Powerhouse, June, Centre for Cities, London.

Charles, D.R. and Benneworth, P, 2001, Are we realizing our potential? Joining up science and technology policy in English Regions. Regional Studies 35(1) 73-79

CLES, 2015, Creating a good local economy. The role of anchor institutions. Manchester: Centre for Local Economic Strategy.

Cookson C, 2013, Building on London's scientific tradition. Financial Times, 4 December 2013.

Curry, S., 2016, Why the Higher Education and Research Bill must be amended. The Guardian, 18 October 2016

Donald, A., 2017, All eyes are on Sir Mark Walport, the new supremo of UK science. The Guardian, 9 February 2017.

Ehlenz, Meagan M. 2015. 'Neighborhood Revitalization and the Anchor Institution'. Urban Affairs Review 52 (5): 714-50.

Else, H., 2015, N8 remains optimistic despite REF slide. Times Higher Education. April 9, 2015.

Flanagan K and Keenan MP, 1998, "Trends in UK Science Policy” in Cunningham, PN (ed.) Science and Technology in the United Kingdom. Cartermill, UK.

Flanagan K, 2017, “The Six Billion Dollar Man”, Research Fortnight, 15 February 2017.

Flanagan K, Uyarra E and Kitagawa F, 2017 forthcoming, 'The university as a city-regional governance actor: the case of the University of Manchester in Greater Manchester' in Ingallina P and Charles D (eds) The Urban University and the Knowledge Economy: New Spaces of Interaction. London: Routledge. 
Greenhalgh, T, Raftery, J, Hanney, S and Glover, M, 2016, Research impact: a narrative review. BMC Medicine 14:78 DOI 10.1186/s12916-016-0620-8

HEFCE, 2016, Consultation on the second Research Excellence Framework. Bristol; Higher Education Funding Council for England, 8 December 2016

HM Government, 2017, Building our Industrial Strategy. Green Paper. HM Government, January 2017.

HM Treasury, 2016, Northern Powerhouse strategy. HM Treasury, November 2016

HM Treasury and BIS, 2014, Our plan for growth: science and innovation Cm 8980, December 2014, Her Majesty's Treasury and Department for Business, Innovation and Skills.

HM Treasury, 2015, Summer Budget, Her Majesty's Treasury, July 2015.

House of Lords, 2003, Science and the RDAs: SETting the regional agenda, Fifth Report of the House of Lords Select Committee on Science and Technology.

Kingman, J, 2016). UK Research and Innovation: 'nine brains in one body'. Times Higher Education, 2 June 2016

Kitagawa, F. 2004. Universities and regional advantage: higher education and innovation policies in English regions. European Planning Studies 12, 6. pp. 835-852.

Lawton Smith H, 2007, "Universities, innovation, and territorial development: A review of the evidence", Environment and Planning C: Government and Policy 25, pp. 98-114.

Lowe N and Feldman M, 2008, "Constructing entrepreneurial advantage: consensus building, technological uncertainty and emerging industries" Cambridge J Regions Econ Soc 1(2): $265-284$.

McKenzie L, 2016, "Regional science audits 'lacking in hard data", Research Fortnight, 23 November 2016.

McLeish, T, 2015, New science policy initiatives threaten to destroy UK's research excellence. The Conversation, 13 January 2015. https://theconversation.com/new-sciencepolicy-initiatives-threaten-to-destroy-uks-research-excellence-36147 (accessed 14 Feb 2017)

Merton R K, 1968, The Matthew Effect in Science. Science. 159 pp.56-62. (5 January 1968).

Nathan, M, 2015, After Florida: Towards an economics of diversity. European Urban and Regional Studies. 22(1) 3-19.

Nightingale P and Coad A, 2014, "The myth of the science park economy" DEMOS Quarterly, Issue 2, 23 April 2014.

Osborne G, 2014, "We need a Northern Powerhouse", Speech by the Chancellor of the Exchequer George Osborne at the Museum of Science and Industry, Manchester on 23 June 2014. https://www.gov.uk/government/speeches/chancellor-we-need-a-northern-powerhouse (accessed 21 February 2017)

Perraudin, F, 2016, BIS confirms Sheffield office will close with jobs moving to London. The Guardian, 26 May 2016

Perry B, 2007, The Multi-level Governance of Science Policy in England Regional Studies 41, pp1051- 1067

Perry B, 2008, "Academic knowledge and urban development: theory, policy and practice" in Tan Yigitcanlar, Koray Velibeyoglu, and Scott Baum (eds) Knowledge-Based Urban 
Development. Planning and Applications in the Information Era, IGI Global, Hershey PA and London UK, pp21-41.

Rankin J, 2013, “AstraZeneca's move south will leave the north-west without a vital element" The Observer, 31 March 2013.

Rigby, E, 2015, Sajid Javid raises doubts over industrial policy. Financial Times. 1 July 2015

Uyarra E, 2010, Conceptualizing the regional roles of universities, implications and contradictions. European Planning Studies 18: pp1227-1246.

Uyarra, E 2010. Conceptualizing the regional roles of universities, implications and contradictions. European Planning Studies, 18: 1227-1246.

Warren L, Kitagawa F and Eatough M, 2009, Developing the knowledge economy through university linkages: An exploration of RDA strategies through case studies of two English regions, International Journal of Entrepreneurship and Innovation 11.

Wilsdon, J, 2015, Sajid Javid's blueprint for BIS heightens fears for research funding. The Guardian. 1 October 2015.

Wilsdon, J, 2016, UKRI if you want to: how to read the new research landscape.

Wonkhe.com, 18 May 2016 http://wonkhe.com/blogs/analysis-ukri-if-you-want-to-how-toread-the-new-research-funding-landscape/ (accessed 15 Feb 2017)

Wilsdon, J, Flanagan, K and Westlake S, 2016. What will an extra $£ 4.7$ billion do for UK science and innovation? The Guardian, 24 November 2016

Work Foundation, 2006, Ideopolis: Manchester Case Study. January 2006. London: Work Foundation.

Wray, F and Charles, D 2009 Science Fiction? Science Cities in an International Context, Report to NESTA. KITE, Newcastle University. 